\title{
Introduction to the special issue on public finance, public debt and global recovery
}

\author{
Jack Mintz • Michael Smart
}

Published online: 25 July 2013

(C) Springer Science+Business Media New York 2013

The edited papers in this special issue of International Tax and Public Finance are drawn from the 68th Congress of the International Institute of Public Finance with a focus on Public Finance, Public Debt and Global Recovery. Of the eight papers accepted for publication here, two were lectures provided at the Congress.

As part of the global economic downturn, we witness migratory shifts induced by economic and fiscal factors in some cases reversing trends in the past (Ireland being a classic example). Assaf Razin in his Congress lecture on "Migration into the Welfare State: Tax and Migration Competition" observes that the United States has primarily attracted skilled workers while Europe has attracted unskilled migrants in recent years. Razin provides empirical work on fiscal effects on skilled migration as well as new theoretical work on tax competition for capital, which can make it more difficult to raise revenues to fund public spending programs. Unlike the Tiebout model, Razin explicitly models the distribution of skills through migration. Tax competition for capital is not efficient with fiscally induced labor migration.

The Euro crisis has been an issue that continues to affect international financial markets in 2013, well after the original 2008 credit crunch arising from the subprime mortgage default in the United States. The European experiment with a monetary union without a political union has been directly challenged by a sovereign debt crisis. On one hand, the European Bank provides important lender-of-last support to European banks. On the other hand, transfers through the banking sector to the Southern countries result in taxpayers in stronger countries like Germany potentially picking

J. Mintz

School of Public Policy, University of Calgary, Calgary, Canada

M. Smart ( $\varangle)$

Department of Economics, University of Toronto, Toronto, Canada

e-mail:msmart@chass.utoronto.ca 
up the tab to support stressed economies. Christophe Schmidt's lecture written with Benjamin Weigert on "Weathering the Crisis and Beyond: Perspective for the Euro Area," reviews the current crisis and provides a specific approach to solve this ongoing Euro crisis. Based on various contributions made by the German Council of Economic Experts, the paper suggests that bad sovereign debt be put in a trust that over time will be covered by contributions made by all EU countries to retire the debt, rather than allow the European Bank to amalgamate monetary and fiscal policies. The architecture would also include a new governance structure to ensure that fiscal policies and financial regulatory policies are supportive of the monetary union.

The remainder of the papers in this volume was submitted for publication after presentations at the Congress. S.M. Ali Abbas and Alexander Klemm examine the fiscal challenges to the corporate tax in "A Partial Race to the Bottom: Corporate Tax Developments in Emerging and Developing Economies". Like advanced countries, developing and emerging economies have been reducing tax rates or providing special regimes such as tax holidays to attract capital. Abbas and Klemm find that developing countries generally have followed advanced countries in reducing rates but have been more vigorous in applying special regimes. In the case of Africa, rates have fallen close to zero in the parallel tax system.

Of course, in today's connected world, tax competition and mobile tax bases are a significant issue faced by public officials in designing tax policies. Sebastian Kessing and Bernhard Koldert in their paper on "Cross-border Shopping and the AtkinsonStiglitz Theorem" provide some new results on whether indirect taxes should be differentiated across goods and services in face of cross-border shopping. They show that even if countries are asymmetric and the Atkinson-Stiglitz conditions still hold, indirect taxes should be zero and therefore not differentiated. However, if governments must rely on indirect taxation, differentiation is appropriate accounting for the sensitivity of tax bases to cross-border shopping.

Peter Egger, Doina Radulescu, and Nora Strecher consider a different tax competition problem in the paper entitled "Effective Labor Taxation and the International Location of Headquarters". While it is well known that capital taxation can influence the choice of where to put headquarters, it is less well known whether labor taxes including progressive income taxes and social security taxes might also affect headquarter location decisions. The authors find that a 1-percentage point in labor taxes reduces the probability of attracting headquarters by 6.1 percent.

With various economic and social changes in society, governments have also found that their tax systems have had to respond to new trends. An example is with respect to the taxation unit of families. Spencer Bastani considers these issues in "GenderBased and Couple-Based Taxation", whereby tax rates are conditioned either on gender or on size of the unit. In a household bargaining model, Bastani finds that threat points that are internal to the marriage (rather than determined by outside opportunities) lead to gender-based tax rates. However, a full optimum can be achieved with tax rates varying by size (single vs. couple) and gender) and these gains can be 2.4 to 4.7 percent of aggregate income as estimated in a simulation for Sweden if the male-female gap is more than 5 percent.

Christian Bjornskov and Niklas Potrafke investigate how party ideology influences the conduct of government in "The Size and Scope of Government in the U.S. States: 
Does Political Ideology Matter?" Their analysis of public sector size, tax structure and labour market regulation in 49 U.S. states is based on a new data set that maps ideology across U.S. legislatures. In their work, which carefully accounts for divided state governments, the authors suggest that divided governments constrain ideologically driven politicians. Their main result is that Republican governors tend to more active in deregulating labor markets, consistent with observed right-to-work legislation that has been recently adopted in some northern U.S. states since 2009.

Another response of fiscally constrained governments is to revamp tax structures. The Value Added Tax has become one of the prominent taxes in the last half century to help over the cost of public services. Sijbren Cnossen in his paper "Preparing the Way for a Modern GST in India" examines the difficulty of developing and administrating a VAT in India with sub-national governments having access to the tax field as well. The constitution limits the Indian central government to taxes on manufactured goods and services (as well as excise duties on tobacco). The states can apply tax on the sale and purchase of goods, and certain other selective excise taxes. Cnossen argues that both the central and the state governments should have access to a full GST base that need not be uniform for the center and states.

As editors of this special issue, we wish to thank the authors and referees who contributed to the richness of this volume. We also wish to thank the editors of International Tax and Public Finance for their advice in planning this volume. We are pleased that this volume provides a partial record of the impressive public finance analysis presented at the 68th Congress of the International Institute of Public Finance. 